\title{
Acholeplasma vituli sp. nov., from bovine serum and cell cultures
}

\author{
A. F. Angulo, ${ }^{1}$ R. Reijgers, ${ }^{1}$ J. Brugman, ${ }^{1}$ I. Kroesen, ${ }^{1}$ F. E. N. Hekkens, ${ }^{1}$ \\ P. Carle, ${ }^{2}$ J. M. Bové, ${ }^{2}$ J. G. Tully, ${ }^{3}$ A. C. Hill, ${ }^{4}$ L. M. Schouls, ${ }^{1}$ C. S. Schot, ${ }^{1}$ \\ P. J. M. Roholl ${ }^{1}$ and A. A. Polak-Vogelzang ${ }^{1}$
}

Author for correspondence: A. F. Angulo. Tel: +313027424 80. Fax: +31 302744420 . e-mail: a.angulo@rivm.nl

\footnotetext{
${ }^{1}$ National Institute of Public Health and the Environment, 3720 BA Bilthoven, The Netherlands

2 Laboratoire de Biologie Cellulaire et Moléculaire, Institut National de la Recherche Agronomique and Université de Bordeaux II, 33883 Villenave d'Ornon Cedex France

3 Mycoplasma Section, National Institute of Allergy and Infectious Diseases, Frederick Cancer Research and Development Center, Frederick, MD 21702, USA

${ }^{4}$ Medical Research Council Toxicology Unit, Carshalton SM5 4EF, UK
}

\begin{abstract}
Organisms isolated from commercial foetal bovine serum and from cell culture lines containing such serum supplements were found to consist of non-helical, non-motile, pleomorphic coccoid forms. One strain (FC 097-2 ${ }^{\top}$ ) cultivated directly from foetal bovine serum was selected for characterization. In ultrastructural examination, individual round cells lacked cell wall structures and cells varied in size, with a mean diameter of about $700 \mathrm{~nm}$. However, variable numbers of cells were filterable through membranes of $300 \mathbf{~ n m}$. Optimum growth occurred between 30 and $37^{\circ} \mathrm{C}$. The organism fermented glucose, fructose and mannose, but did not hydrolyse arginine. The strain was insensitive to $500 \mathrm{U}$ penicillin $\mathrm{ml}^{-1}$ and was capable of growing in the absence of serum or cholesterol. The organism was serologically distinct from all 13 currently described species in the genus Acholeplasma and from other sterolrequiring species in the genus Mycoplasma, using growth inhibition, immunoperoxidase and immunofluorescence tests. Strain FC $097-2^{\top}$ was found to have a DNA G+C composition between $37 \cdot 6 \pm 1 \mathrm{~mol} \%$ and $38 \cdot 3 \pm 1 \mathrm{~mol} \%$. The genome size was determined to be $2095 \mathrm{kbp}$. The $16 \mathrm{~S}$ rDNA sequence of strain FC 097-2 ${ }^{\top}$ was compared to $16 \mathrm{~S}$ rDNA sequences of other mollicutes in nucleotide databases. No deposited sequence was found to be identical; the closest relatives were several members of the genus Acholeplasma. On the basis of these findings and other similarities to acholeplasmas in morphology and growth, the absence of a sterol requirement for growth, and similar genomic characteristics, the organism was assigned to the genus Acholeplasma. Strain FC 097-2 ${ }^{\top}$ is designated the type strain (ATCC $700667^{\top}$ ) of a new species, Acholeplasma vituli.
\end{abstract}

Keywords: Acholeplasma vituli sp. nov., taxonomy, description

\section{INTRODUCTION}

One of the more important sources of mollicute contamination in eukaryotic cell culture systems comes from Mycoplasma or Acholeplasma species present in bovine or other animal serum supplements used in such cell cultivation. Although significant improvement in eradicating mollicutes from serum supplements has come about with ultrafiltration (passage

Abbreviations: Bd, buoyant density method; Tm, melting temperature method.

The GenBank accession number for the 16S rRNA gene sequence of strain FC $097-2^{\top}$ is AF031479. through pore diameters of $35-40 \mathrm{~nm})$ of some commercial foetal bovine serum products (Tully, 1996), the cost and other availability factors have frequently limited the use of such products. It is therefore important to continue to identify and characterize new mollicutes occurring in animal serum products in order to provide a rapid and comprehensive detection scheme to identify the origin of such cell culture contaminants. A mollicute was isolated more than five times from several lots of foetal calf serum and later from at least six eukaryotic cell cultures from various laboratories in the period 1979-1992. All of these isolates presented similar characteristics and appeared to be identical in several serological tests. In this paper, the first isolate in this series is described and charac- 
terized and a species designation within the genus Acholeplasma is proposed.

\section{METHODS}

Isolation procedure. Strain FC $097-2^{\mathrm{T}}$ was isolated from a foetal calf serum lot, using a technique whereby $15-20 \%$ of the test animal serum was incorporated into a standard mycoplasma liquid medium formulation in place of the usual serum supplement (Barile \& Kern, 1971). The liquid medium contained $0.2 \%$ arginine but was without further serum supplements (Polak-Vogelzang et al., 1980). Following incubation at $37^{\circ} \mathrm{C}$, subcultivations were made to agar plates for colony growth and for selection of individual colonies, with plates being incubated aerobically at $37^{\circ} \mathrm{C}$. Small pieces of agar containing single mollicute colonies were selected and streaked onto fresh agar plates. After incubation of these plates for $4 \mathrm{~d}$, this process was repeated and the colonies obtained from the second agar passage were inoculated into the broth medium. After $3 \mathrm{~d}$ incubation at the temperature noted, each broth culture was filtered through membrane filters (Sartorius) with a pore diameter of $300 \mathrm{~nm}$. The filtrate was diluted tenfold and each dilution was inoculated onto agar plates to obtain single colonies. This cloning was repeated once. One of the clones was designated FC 097-2 .

Culture medium and cultivation techniques. The media used in this study for the culture of strain FC $097-2^{\mathrm{T}}$ and for the mycoplasmas and acholeplasmas employed in the serological testing was Herderschêe medium containing $20 \%$ horse serum (Polak-Vogelzang et al., 1980) or two other formulations described previously (Hill, 1971; TaylorRobinson et al., 1968). The purified agar in the growth medium was Lab M agar. Depending on their biochemical activities, the mycoplasmas were grown in liquid medium containing $1 \%(\mathrm{w} / \mathrm{v})$ glucose $(\mathrm{pH} 7 \cdot 8)$ or in liquid medium containing $0 \cdot 2-1 \cdot 0 \%(\mathrm{w} / \mathrm{v})$ arginine $(\mathrm{pH} 7 \cdot 3)$, and with $500 \mathrm{U}$ penicillin $\mathrm{ml}^{-1}$. Species grown in $1.0 \%$ arginine were not inhibited by this concentration. Mycoplasma genitalium and Mycoplasma synoviae were grown in SP-4 broth or agar medium (Tully et al., 1977). Agar cultures were incubated at $35-37^{\circ} \mathrm{C}$, either aerobically in a humid chamber or under anaerobic conditions in either a GasPak system (BBL Microbiology Systems) or in a $\mathrm{CO}_{2}$-plus- $\mathrm{N}_{2}$-enriched atmosphere. Liquid cultures were stored at $-70^{\circ} \mathrm{C}$ in ampoules.

Morphological studies. Mycoplasma colonies grown on agar were examined microscopically at $100 \times$ magnification after 2, 7 and $14 \mathrm{~d}$ incubation. The colonies were transferred to slides and stained with Giemsa stain (Fallon \& Whittlestone, 1969; Klieneberger-Nobel, 1962). Liquid cultures were observed several times under dark-field microscopy and the micro-organisms were stained with Giemsa stain. Organisms grown in broth were harvested by centrifugation at $30000 \mathrm{~g}$ for $45 \mathrm{~min}$. Cell pellets prepared for electron microscopy were fixed in cacodylate-buffered paraformalin and glutaraldehyde (final concentrations of $2 \cdot 5 \%$ and $2 \cdot 5 \%$ at $\mathrm{pH} 7 \cdot 6$, respectively), with and without tannic acid (1\%) for $24 \mathrm{~h}$, then washed in cacodylate buffer and post-fixed for $2 \mathrm{~h}$ in $1 \%(\mathrm{w} / \mathrm{v})$ osmium tetroxide with $1.5 \%$ ferrocyanide in $0 \cdot 1 \mathrm{M}$ cacodylate buffer (Karnovsky, 1971). Dehydration followed with embedding in epoxy resin glycidether 100 (Merck). Ultrathin sections were contrasted with aqueous uranyl acetate $(2 \%, \mathrm{w} / \mathrm{v})$ and lead citrate $(1 \%, \mathrm{w} / \mathrm{v})$ with a LKB ultrastainer and examined in an electron microscope (Philips EM 201/400) operating at $80 \mathrm{kV}$.
Sterol requirement. Single colonies of strain FC 097-2 ${ }^{\mathrm{T}}$, were seeded onto serum-free solid medium supplemented with $0.05 \%$ bovine serum albumin, $0.05 \%$ glucose and $10 \mu \mathrm{g}$ palmitic acid $\mathrm{ml}^{-1}$. Cholesterol, dissolved in Tween 80 , was added to give concentrations of $20,10,5$ and $1 \mu \mathrm{g} \mathrm{m} \mathrm{m}^{-1}$. Plates containing no cholesterol were included (Edward, 1971; Edward \& Fitzgerald, 1951; Razin \& Tully, 1970; Tully \& Razin, 1969). The micro-organisms were also subcultured onto the basal agar medium without serum. When growth occurred on any of the serum-free media, single colonies were passaged three times on similar plates to ensure that growth was not due to a carry-over of serum from the original culture, giving misleading results. The strain was tested indirectly for sterol dependence by a paper disk method (Freundt et al., 1973) using either dried disks that originally contained $0.02 \mathrm{ml} 1.5 \%(\mathrm{w} / \mathrm{v})$ ethanolic solution of digitonin (Sigma) or wet disks that contained $0.02 \mathrm{ml} 20 \%(\mathrm{w} / \mathrm{v})$ aqueous solution of sodium polyanetholesulfonate (Koch-Light Laboratories) on basal growth medium containing Lab $\mathrm{M}$ agar. The width of zones of growth inhibition was measured in millimetres. Also, the ability of strain FC $097-2^{\mathrm{T}}$ to maintain sustained growth in serum-free medium was tested following the serial dilution technique described earlier (Rose et al., 1993).

Tests for biological and biochemical properties. Strain FC 097-2 $2^{\mathrm{T}}$ was examined for: metabolism of arabinose, arbutin, cellobiose, dulcitol, fructose, galactose, glucose, glycerol, inositol, lactose, maltose, mannitol, mannose, raffinose, rhamnose, salicin, sorbitol, sucrose and trehalose; hydrolysis of aesculin, $1 \cdot 0 \%$ and $0 \cdot 1 \%$ arginine, and urea; reduction of methylene blue, resazurin, tetrazolium and tellurite; and phosphatase activity (Aluotto et al., 1970; Barber \& Fabricant, 1971; Leach, 1976; Shepard \& Howard, 1970; Tully, 1965; Williams \& Wittler, 1971). Temperature requirements for growth were determined aerobically with broth cultures incubated at 25, 30, 32 and $37^{\circ} \mathrm{C}$ (Williamson et al., 1996). The level of sensitivity to methylene blue was determined by adding $0.002 \%(\mathrm{w} / \mathrm{v})$ methylene blue to the basal solid medium, and the growth of inoculated mycoplasmas was compared with the growth of mycoplasmas cultivated on agar medium without methylene blue. Lipolytic activity was tested by inoculating mycoplasmas onto basal solid medium enriched with $10 \%$ egg yolk emulsion (Fabricant \& Freundt, 1967), with plates incubated aerobically and examined after 3, 7 and $14 \mathrm{~d}$ for visual evidence of lipolysis (clearing) or film production. The strain was also examined for haemolytic activity, haemadsorption and haemagglutination with chick, guinea pig and sheep erythrocytes (Aluotto et al., 1970; Manchee \& Taylor-Robinson, 1968).

Filtration characteristics of strain FC $097-2^{\mathrm{T}}$ were determined with a $24 \mathrm{~h}$ culture diluted $1: 10$ in liquid medium and then filtered through a series of membrane filters (Millipore) with pore diameters of 220, 300, 450, 650 and $800 \mathrm{~nm}$. For each filtrate, the number of c.f.u. per ml was determined by plating onto an agar medium; the number obtained was compared with the number in the unfiltered culture dilution. The strain was also tested for possible reversion to conventional bacterial forms by examining five consecutive passages of the organism on both solid and liquid media that contained no microbial inhibitors. Agar colonies of the cloned line were also treated with Dienes stain in order to further differentiate mycoplasma colonies from bacterial Lforms (Timms, 1967).

Genomic analysis. To extract and prepare DNA, the strain was grown in Herderschêe broth and pelleted by centrifugation at $20000 \mathrm{~g}$. The DNA was extracted and purified by 
Table 1. Strains used for the sequencing in order to establish the relatedness of Acholeplasma vituli

\begin{tabular}{|c|c|c|c|}
\hline Species & Accession no. & Strain & ATCC no. \\
\hline Mycoplasma bovis & U02968 & Donetta $^{\mathrm{T}}$ & ATCC $25523^{\mathrm{T}}$ \\
\hline Mycoplasma fermentans & M24289 & $\mathrm{PG} 18^{\mathrm{T}}$ & ATCC $19989^{\mathrm{T}}$ \\
\hline Mycoplasma lipophilum & M24581 & $\mathrm{MaBy}^{\mathrm{T}}$ & ATCC $27104^{\mathrm{T}}$ \\
\hline Mycoplasma hyorhinis & M24658 & $\mathrm{BTS}^{\mathrm{T}}$ & ATCC $17981^{\mathrm{T}}$ \\
\hline Mycoplasma arginini & M24579 & $\mathrm{G} 230^{\mathrm{T}}$ & ATCC $23838^{\mathrm{T}}$ \\
\hline Mycoplasma hominis & M24473 & $\mathrm{PG} 21^{\mathrm{T}}$ & ATCC $23114^{\mathrm{T}}$ \\
\hline Mycoplasma orale & M24659 & $\mathrm{CH}-19299^{\mathrm{T}}$ & ATCC $23714^{\mathrm{T}}$ \\
\hline Mycoplasma salivarium & M24661 & PG $20^{\mathrm{T}}$ & ATCC $23064^{\mathrm{T}}$ \\
\hline Mycoplasma pirum & M23940 & HRC $70-159^{\mathrm{T}}$ & ATCC $25960^{\mathrm{T}}$ \\
\hline Mycoplasma pneumoniae & M29061 & $\mathrm{FH}^{\mathrm{T}}$ & ATCC $15531^{\mathrm{T}}$ \\
\hline Mycoplasma iowae & M24293 & $695^{\mathrm{T}}$ & ATCC $33552^{\mathrm{T}}$ \\
\hline Acholeplasma laidlawii & M23932 & $\mathrm{PG}^{\mathrm{T}}$ & ATCC $23206^{\mathrm{T}}$ \\
\hline Acholeplasma oculi & U14904 & $19 \mathrm{~L}^{\mathrm{T}}$ & ATCC $27350^{\mathrm{T}}$ \\
\hline Phytoplasma sp. & Y11933 & ESFY & None \\
\hline Acholeplasma modicum & M23933 & $\mathrm{PG} 49^{\mathrm{T}}$ & ATCC $29102^{\mathrm{T}}$ \\
\hline Entomoplasma ellychniae & M24292 & ELCN-1 ${ }^{\mathrm{T}}$ & ATCC $43707^{\mathrm{T}}$ \\
\hline Mesoplasma entomophilum & M23931 & $\mathrm{TAC}^{\mathrm{T}}$ & ATCC $43706^{\mathrm{T}}$ \\
\hline
\end{tabular}

a procedure described previously (Carle et al., 1983a). The $\mathrm{G}+\mathrm{C}$ content of purified DNA was determined by the buoyant density (Bd) and melting temperature (Tm) methods (Carle et al., 1983b). The $\mathrm{G}+\mathrm{C}$ content was calculated from the mean of four values by Tm and the mean of two Bd estimates. Mesoplasma entomophilum strain $\mathrm{TAC}^{\mathrm{T}}$, which has a previously reported $\mathrm{G}+\mathrm{C}$ content of $30 \pm 1 \mathrm{~mol} \%$ (Tully et al., 1988), was used as control. The genome size was calculated from the mean of four calculations by using a previously published method (Carle et al., 1995).

Serological studies. Antisera to strain FC 097-2 ${ }^{\mathrm{T}}$ were prepared by previously described methods (Hill, 1971; Morton \& Roberts, 1967; Polak-Vogelzang et al., 1978). The agar plate growth inhibition test (Clyde, 1964), metabolism inhibition tests (Hill, 1977; Purcell et al., 1966a, 1966b; Taylor-Robinson et al., 1966), an immunoperoxidase procedure (Hill, 1978; Polak-Vogelzang et al., 1978) and an epiimmunofluorescence test (Gardella et al., 1983) performed on agar colonies were used to compare the response of strain FC $097-2^{\mathrm{T}}$ to hyperimmune antisera with that of previously described Acholeplasma and Mycoplasma species.

Type strains were obtained from the National Collection of Type Cultures, Colindale, UK, and from Drs H. Atobe, M. F. Barile, J. M. Bradbury, R. J. Fallon, E. A. Freundt, J. T. Heywood, P. T. W. Jordan, D. E. Jaspar, H. Kirchhoff, R. H. Leach, G. J. McGarrity, D. L. Rose, G. Smith, D. TaylorRobinson and J. G. Tully. The following type strains were used: Mycoplasma adleri $\mathrm{G} 145^{\mathrm{T}}$; Mycoplasma agalactiae $\mathrm{PG}^{\mathrm{T}}$; Mycoplasma alkalescens PG51 ${ }^{\mathrm{T}}$; Mycoplasma alvi Ilsley ${ }^{\mathrm{T}}$; Mycoplasma anatis $1340^{\mathrm{T}}$; Mycoplasma anseris $1219^{\mathrm{T}}$; Mycoplasma arginini $\mathrm{G} 230^{\mathrm{T}}$; Mycoplasma arthritidis PG6 $^{\mathrm{T}} ;$ Mycoplasma auris $\mathrm{UIA}^{\mathrm{T}}$; Mycoplasma bovigenitalium PG11 ${ }^{\mathrm{T}}$; Mycoplasma bovirhinis PG43 ${ }^{\mathrm{T}}$; Mycoplasma bovis PG45 $^{\mathrm{T}}$; Mycoplasma bovoculi M165/69 ${ }^{\mathrm{T}}$; Mycoplasma

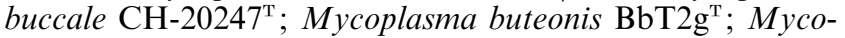
plasma californicum ST-6 ${ }^{\mathrm{T}}$; Mycoplasma canadense $275 \mathrm{C}^{\mathrm{T}}$; Mycoplasma canis PG14 ${ }^{\mathrm{T}}$; Mycoplasma capricolum subsp. capricolum California kid ${ }^{\mathrm{T}}$; Mycoplasma capricolum subsp. capripneumoniae $\mathrm{F} 38^{\mathrm{T}}$; Mycoplasma caviae $\mathrm{G} 122^{\mathrm{T}}$; Mycoplasma cavipharyngis $117 \mathrm{C}^{\mathrm{T}}$; Mycoplasma citelli $\mathrm{RG}-2 \mathrm{C}^{\mathrm{T}}$; Mycoplasma cloacale $383^{\mathrm{T}}$; Mycoplasma collis $58 \mathrm{~B}^{\mathrm{T}}$; Mycoplasma columbinasale $694^{\mathrm{T}}$; Mycoplasma columbinum $\mathrm{MMP}^{\mathrm{T}}$; Mycoplasma columborale MMP4 ${ }^{\mathrm{T}}$; Mycoplasma conjunctivae $\mathrm{HRC} 581^{\mathrm{T}}$; Mycoplasma corogypsi $\mathrm{BV} 1^{\mathrm{T}} ;$ Mycoplasma cottewii VIS ; Mycoplasma cricetuli $\mathrm{CH}^{\mathrm{T}}$; Mycoplasma cynos $\mathrm{H} 831^{\mathrm{T}}$; Mycoplasma dispar 462/2 ${ }^{\mathrm{T}}$; Mycoplasma edwardii PG $24^{\mathrm{T}}$; Mycoplasma equigenitalium $\mathrm{T} 37^{\mathrm{T}}$; Mycoplasma equirhinis M432/72 ${ }^{\mathrm{T}}$; Mycoplasma falconis $\mathrm{H} / \mathrm{T}^{\mathrm{T}}$; Mycoplasma fastidiosum 4822 ; Mycoplasma faucium $\mathrm{DC} 333^{\mathrm{T}}$; Mycoplasma felifaucium $\mathrm{PU}^{\mathrm{T}} ;$ Mycoplasma feliminutum $\mathrm{Ben}^{\mathrm{T}}$; Mycoplasma felis $\mathrm{CO}^{\mathrm{T}}$; Mycoplasma fermentans $\mathrm{PG} 18^{\mathrm{T}}$; Mycoplasma flocculare $\mathrm{Ms}^{4} 2^{\mathrm{T}}$; Mycoplasma gallinaceum $\mathrm{DD}^{\mathrm{T}} ;$ Mycoplasma gallinarum PG16 ${ }^{\mathrm{T}}$; Mycoplasma gallisepticum PG31 ${ }^{\mathrm{T}}$; Mycoplasma gallopavonis WR1 ${ }^{\mathrm{T}}$; Mycoplasma gateae $\mathrm{CS}^{\mathrm{T}}$; Mycoplasma genitalium G-37 ; Mycoplasma glycophilum $486^{\mathrm{T}}$; Mycoplasma gypis $\mathrm{B} 1 / \mathrm{T}^{\mathrm{T}}$; Mycoplasma hominis $\mathrm{PG} 21^{\mathrm{T}}$; Mycoplasma hyopharyngis $\mathrm{H} 3-6 \mathrm{BF}^{\mathrm{T}}$; Mycoplasma hyopneumoniae $\mathrm{J}^{\mathrm{T}} ;$ Mycoplasma hyorhinis $\mathrm{BTS} 7^{\mathrm{T}} ;$ Mycoplasma hyosynoviae $\mathrm{S} 16^{\mathrm{T}} ;$ Mycoplasma imitans $4229^{\mathrm{T}} ;$ Mycoplasma indiense $3 \mathrm{~T}^{\mathrm{T}}$; Mycoplasma iners PC30 ${ }^{\mathrm{T}}$; Mycoplasma iowae 695 ${ }^{\mathrm{T}}$; Mycoplasma lagogenitalium $12 \mathrm{MS}^{\mathrm{T}}$; Mycoplasma leonicaptivi $3 \mathrm{~L} 2^{\mathrm{T}}$; Mycoplasma leopharyngis $\mathrm{LL}^{\mathrm{T}}$; Mycoplasma lipofaciens $\mathrm{R} 171^{\mathrm{T}}$; Mycoplasma lipophilum $\mathrm{MaBy}^{\mathrm{T}}$; Mycoplasma maculosum PG15 $5^{\mathrm{T}}$; Mcoplasma meleagridis $17529^{\mathrm{T}}$; Mycoplasma moatsii MK 405 ; Mycoplasma mobile $163 \mathrm{~K}^{\mathrm{T}}$; Mycoplasma molare $\mathrm{H} 542^{\mathrm{T}}$; Mycoplasma muris RIII-4 ${ }^{\mathrm{T}}$; Mycoplasma mustelae MX9 ${ }^{\mathrm{T}}$; Mycoplasma mycoides subsp. capri $\mathrm{PG}^{\mathrm{T}}$; Mycoplasma mycoides subsp. mycoides $\mathrm{PG}^{\mathrm{T}}$; Mycoplasma neurolyticum Type $\mathrm{A}^{\mathrm{T}}$; Mycoplasma opalescens MH5408 ${ }^{\mathrm{T}}$; Mycoplasma orale $\mathrm{CH}-19299^{\mathrm{T}}$; Mycoplasma ovipneumoniae Y98 ${ }^{\mathrm{T}}$; Mycoplasma oxoniensis $128^{\mathrm{T}}$; Mycoplasma penetrans GTU-54-6A $1^{\mathrm{T}}$; Mycoplasma pirum $\mathrm{HRC}$ 70-159 $;$ Mycoplasma pneumoniae $\mathrm{FH}^{\mathrm{T}} ;$ Mycoplasma primatum $\mathrm{HRC}_{292^{\mathrm{T}}}$; Mycoplasma pullorum $\mathrm{CKK}^{\mathrm{T}}$; Mycoplasma pulmonis $\mathrm{PG} 34^{\mathrm{T}}$; Mycoplasma putrefaciens $\mathrm{KS}-1^{\mathrm{T}}$; Mycoplasma salivarium $\mathrm{PG} 20^{\mathrm{T}}$; Mycoplasma simbae $\mathrm{LX}^{\mathrm{T}}$; Mycoplasma spermatophilum AH159 ${ }^{\mathrm{T}}$; Mycoplasma 
spumans $\mathrm{PG}^{\mathrm{T}}$; Mycoplasma sualvi Mayfield $\mathrm{B}^{\mathrm{T}}$; Mycoplasma subdolum $\mathrm{TB}^{\mathrm{T}}$; Mycoplasma synoviae WVU $1853^{\mathrm{T}}$; Mycoplasma testudinis $01008^{\mathrm{T}}$; Mycoplasma yeatsii $\mathrm{GIH}^{\mathrm{T}}$; and Mycoplasma verecundum $107^{\mathrm{T}}$.

The following Acholeplasma species, all type strains, were used in the study: Acholeplasma axanthum S-743 ${ }^{\mathrm{T}}$; Acholeplasma brassicae $0502^{\mathrm{T}}$; Acholeplasma cavigenitalium $\mathrm{GP}^{\mathrm{T}}$; Acholeplasma equifetale $\mathrm{C} 112^{\mathrm{T}}$; Acholeplasma granularum BTS-39 ${ }^{\mathrm{T}}$; Acholeplasma hippikon $\mathrm{Cl}^{\mathrm{T}}$; Acholeplasma laidlawii PG8 ${ }^{\mathrm{T}}$; Acholeplasma modicum PG49 ${ }^{\mathrm{T}}$; Acholeplasma morum 72-043 ${ }^{\mathrm{T}}$; Acholeplasma multilocale PN525 ${ }^{\mathrm{T}}$; Acholeplasma oculi $19 \mathrm{~L}^{\mathrm{T}}$; Acholeplasma palmae $\mathrm{J} 233^{\mathrm{T}}$; and Acholeplasma parvum $\mathrm{H} 23 \mathrm{M}^{\mathrm{T}}$.

16S rDNA sequence analysis. The $16 \mathrm{~S}$ rRNA gene of strain FC 097-2 ${ }^{\mathrm{T}}$ was amplified using the universal primers 16S8FE (GGA ATT CAG AGT TTG ATC MTG GYT CAG) and 16S556RB (CGG GAT CCC TTT ACG CCC ART RAW TCC G). Both strands of the PCR product were sequenced directly using fluorescent dye terminators in the cycling sequencing system (Perkin-Elmer Cetus). The sequence was compared with the sequences from the EMBL database using the FASTA program (Pearson, 1990). Previously determined mollicute sequences were retrieved from the GenBank database and truncated to fit the 16S rRNA gene sequence lacking the outer primer sites used for PCR. The sequences were compared using the CLUSTAL method in the MEGALIGN module of the DNASTAR software package. The characteristics of strains used are given in Table 1.

\section{RESULTS AND DISCUSSION}

\section{Growth and morphological properties}

Strain FC 097-2 ${ }^{\mathrm{T}}$ grew well in liquid medium under aerobic conditions or in a $\mathrm{CO}_{2}$-enriched atmosphere. Optimal growth occurred at $37^{\circ} \mathrm{C}$ after 3 d incubation, but equal amounts of growth were apparent at both 30 and $32{ }^{\circ} \mathrm{C}$ after $6 \mathrm{~d}$ incubation. Colonies of strain FC $097-2^{\mathrm{T}}$ were visible on subculture after $7 \mathrm{~d}$ incubation under aerobic conditions and in a $\mathrm{CO}_{2}$-plus- $\mathrm{N}_{2}$ enriched atmosphere. The colonies on agar (Fig. 1) had a typical 'fried egg' appearance. Agar growth was inhibited by methylene blue. No film was produced on egg yolk agar and no lipolytic activity was observed.

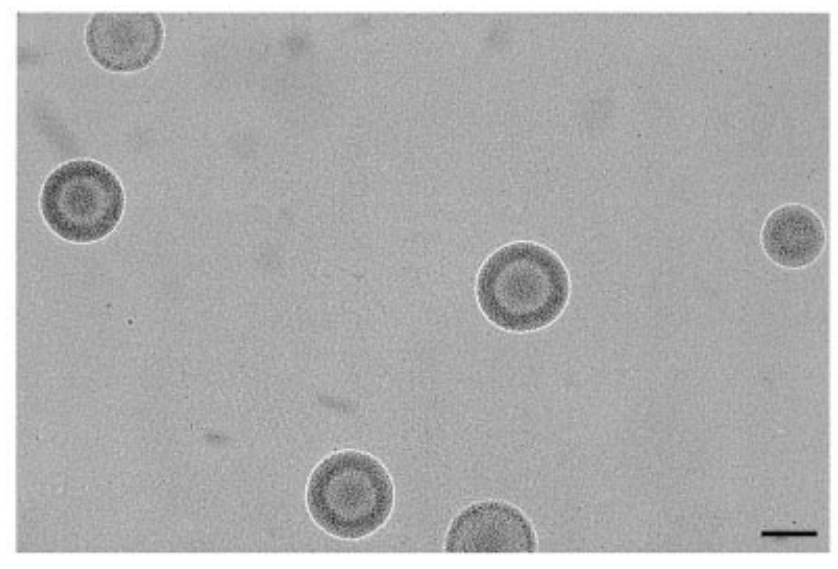

Fig. 1. Colonies of strain FC $097-2^{\top}$ grown under aerobic conditions for $5 \mathrm{~d}$ on Herderschêe agar medium. Bar, $180 \mu \mathrm{m}$.
The strain was not motile and no helical forms were observed when broth cultures were examined under dark-field microscopy. Liquid cultures stained with Giemsa stain contained pleomorphic forms characteristic of mollicutes. The strain did not revert to a bacterial form when subcultured on medium without inhibitors. The colonies rapidly stained with Dienes reagent, confirming the isolate as a true member of the class Mollicutes rather than a bacterial L-form.

The ultrastructure of the organism was typical of the morphology of other mollicutes when thin sections were viewed by electron microscopy (Boatman, 1979). Cells were round with a mean diameter of about $700 \mathrm{~nm}$, their cytoplasm was loosely or compactly filled with varying amounts of ribosomes and nuclear material, and they possessed a single trilaminar symmetrical cell membrane, lacking any evidence of a cell wall structure (Fig. 2a). After tannic acid fixation, a dense $10 \mathrm{~nm}$ surface layer was seen external to the cell membrane (Fig. 2b). Vacuoles were sometimes seen.

\section{Sterol requirement}

Strain FC $097-2^{\mathrm{T}}$ did not require cholesterol for growth since it could be cultured on medium without cholesterol. Tests for sustained growth in serum-free medium established that the strain could be maintained through 24 serial tenfold dilutions in medium devoid of serum. Strain FC $097-2^{\mathrm{T}}$ was not susceptible to digitonin or sodium polyanetholesulfonate, again confirming a characteristic typical of other acholeplasmas that do not require cholesterol or serum for growth.

\section{Biochemical and biological properties}

Strain FC 097-2 $2^{\mathrm{T}}$ fermented glucose, fructose and mannose, reduced tellurite and resazurin, but did not hydrolyse aesculin, arginine or urea, and did not reduce methylene blue and tetrazolium. This strain was haemolytic for all three types of erythrocytes tested, but did not haemadsorb these cells. The strain haemagglutinated only sheep cells. Filtration of a broth culture of the strain reduced the viable count from $2 \times 10^{5}$ c.f.u. per $\mathrm{ml}$ in the original dilution to $7 \times 10^{2}$ c.f.u. per $\mathrm{ml}$ in the $300 \mathrm{~nm}$-pore-size membrane filtrate.

\section{Serological tests}

The four serological tests performed with strain FC $097-2^{\mathrm{T}}$ and the antisera to currently described $\mathrm{Myco-}$ plasma and Acholeplasma species listed above revealed no cross-reaction with any of these reagents: no zones of inhibition were observed around disks saturated with mycoplasma or acholeplasma antisera; the titre in the metabolism inhibition test was 1:16 or lower when this new acholeplasma was tested against antisera to all mycoplasma or acholeplasma; in the indirect immunofluorescence and the immunoperoxidase tests, dilutions of $1: 10$ or lower of mycoplasma and achole- 

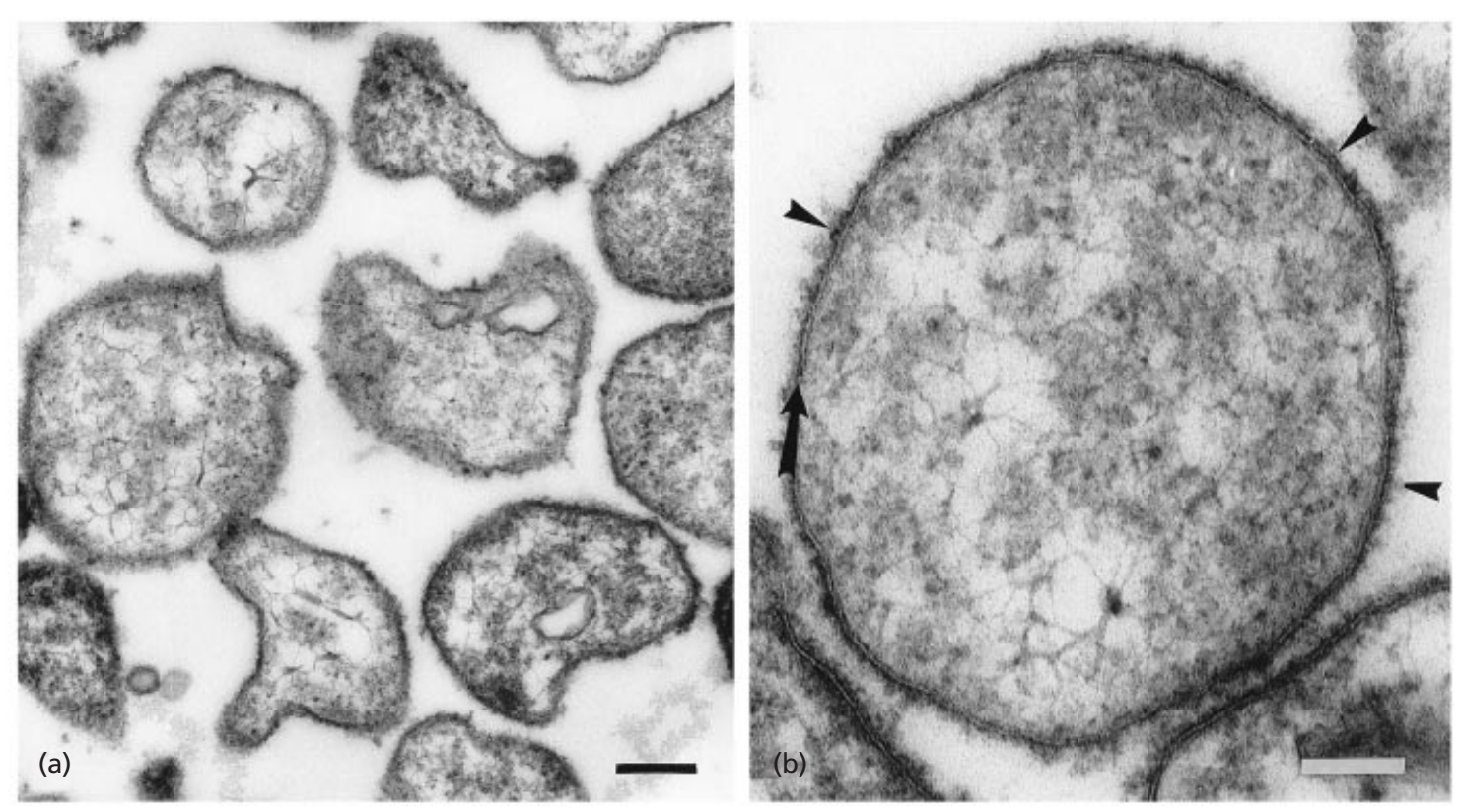

Fig. 2. Electron micrographs of a section of strain $F C 097-2^{\top}$ stained with uranyl acetate and lead citrate showing: (a) the absence of a cell wall (bar, $250 \mathrm{~nm})$; and (b) the presence of a trilaminar membrane (arrows) (bar, $100 \mathrm{~nm}$ ).

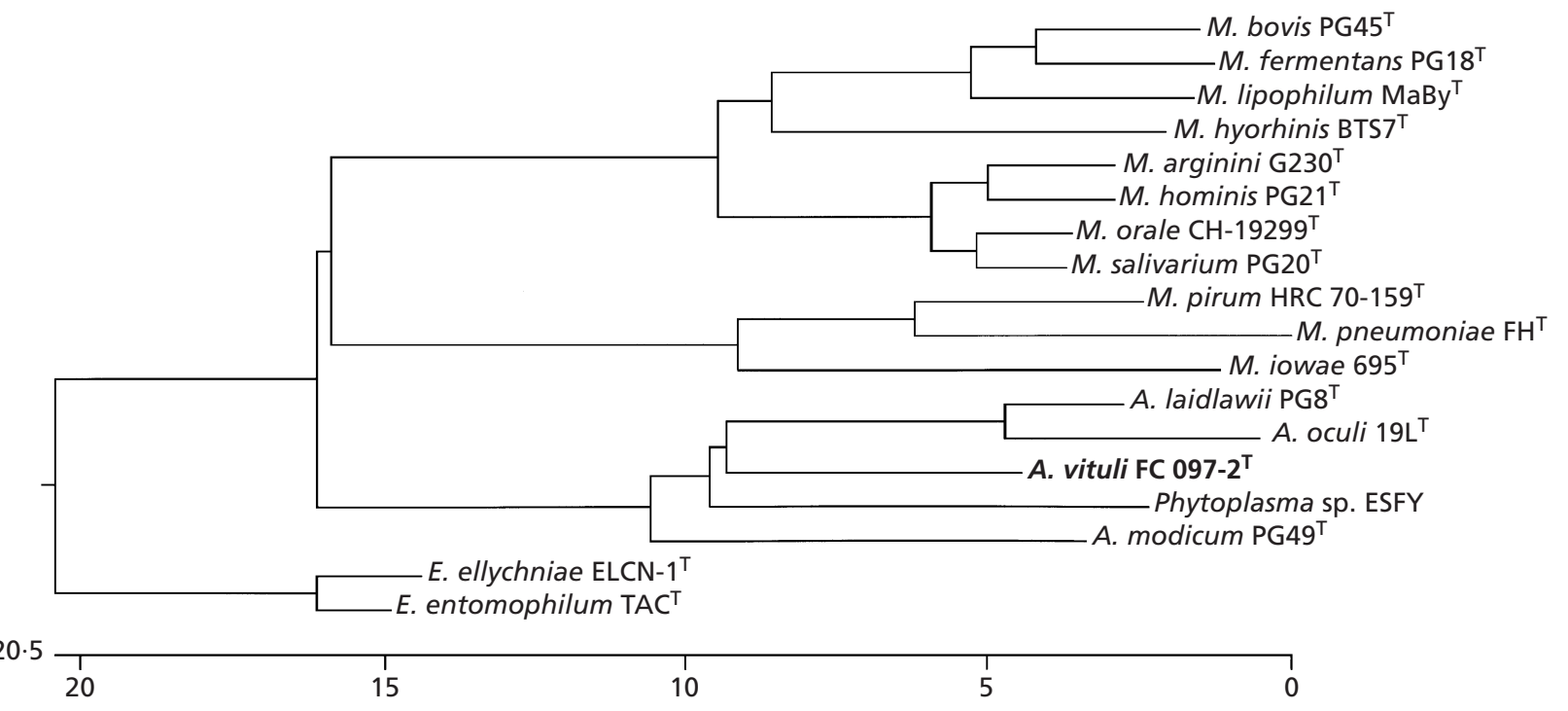

Fig. 3. Unrooted phylogenetic tree showing the relatedness of the $16 \mathrm{~S}$ rRNA gene sequence from strain $\mathrm{FC} 097-2^{\top}$ with those of other mollicutes. The scale beneath the tree measures the distance between sequences. Units indicate the number of substitution events.

plasma antisera failed to stain agar colonies of strain FC 097-2 .

\section{Genomic characterization}

The DNA G + C content of strain FC 097-2 ${ }^{\mathrm{T}}$ calculated from the mean of four Tm estimates was $37 \cdot 6 \pm 1 \mathrm{~mol} \%$, whereas the mean of two Bd estimates was $38 \cdot 3 \pm 1 \mathrm{~mol} \%$. The mean of four estimates of the genome size of this strain was $2095 \mathrm{kbp}$.

\section{Phylogenetic analysis}

Analysis of the 16S rRNA gene sequence revealed that this component in strain FC 097-2 ${ }^{\mathrm{T}}$ comprised $1550 \mathrm{bp}$. Comparison of this sequence with those 
present in the nucleotide databases revealed high similarities with mollicute sequences. The highest similarity found $(88 \%)$ was with the sequence of Phytoplasma sp. strain ESFY. Optimized alignment and clustering showed that the closest relatives of the 16S rRNA gene sequence of strain FC $097-2^{\mathrm{T}}$ were found in the Acholeplasma group. A phylogenetic tree indicating the genetic relatedness with other mollicutes is displayed in Fig. 3. The species and strains used in the nucleotide comparison and their accession numbers are given in Table 1.

\section{Habitat}

The occurrence of FC $097-2^{\mathrm{T}}$ in foetal bovine serum would suggest that the organism is of bovine origin. However, since direct isolation of the organism from either bovines or other animals has not been established, it only remains a strong possibility that the strain is derived from cattle.

\section{Taxonomic assignment}

The properties of strain FC $097-2^{\mathrm{T}}$ described herein fulfil recently revised criteria (International Committee on Systematic Bacteriology Subcommittee on the Taxonomy of Mollicutes, 1995) for new species descriptions in the class Mollicutes. Properties mandating assignment to this class include absence of a cell wall, filterability and resistance to penicillin. The non-helical morphology of the strain, the ability of the strain to grow over a temperature range of $30-37^{\circ} \mathrm{C}$, the inability to hydrolyse urea, a genome size of $2095 \mathrm{kbp}$ and the lack of a sterol requirement for growth place the organism within the order Acholeplasmatales, family Acholeplasmataceae (Tully et al., 1993). Finally, the lack of a serological relationship to other established species currently assigned to the genus Acholeplasma demonstrates its unique status as a new species within this genus. Accordingly, the designation Acholeplasma vituli is proposed for this organism. The taxonomic description below summarizes the properties of the organism.

\section{Description of Acholeplasma vituli sp. nov.}

Acholeplasma vituli [vi.tu'li. L. n. vitulus calf; L. gen. n. vituli of calf, referring to the provenance of the organism (foetal calf serum)].

Cells predominately coccoid in shape, with mean diameter of about $700 \mathrm{~nm}$. Cells devoid of cell wall and surrounded only by a cytoplasmic membrane. Nonmotile and non-helical. Colonies on solid medium demonstrate typical 'fried egg' appearance under both aerobic and anaerobic conditions. Chemoorganotroph. Acid produced from glucose, fructose and mannose. Resazurin and tellurite are reduced. Aesculin, arginine and urea are not hydrolysed. Methylene blue and tetrazolium are not reduced. Casein is not digested. Phosphatase and urease are not produced. No film produced on egg yolk agar and no lipolytic activity observed. Sterol or serum not required for growth. Temperature range of growth is $25-37^{\circ} \mathrm{C}$. Haemolytic for guinea pig, chick and sheep erythrocytes. Sheep erythrocytes are haemagglutinated. Serologically distinct from all other Acholeplasma and Mycoplasma species. Isolated so far only from foetal bovine serum or contaminated cell cultures. The DNA $\mathrm{G}+\mathrm{C}$ content is $38.3 \pm 1 \mathrm{~mol} \%$ ( $\mathrm{Bd}$ method) or $37.6 \pm 1 \mathrm{~mol} \%$ (Tm method). Genome size is $2095 \mathrm{kbp}$. Type strain is FC $097-2^{\mathrm{T}} \quad(=\mathrm{ATCC}$ $\left.700667^{\mathrm{T}}\right)$.

\section{ACKNOWLEDGEMENTS}

We wish to thank Mrs M. C. Burger for assistance with the electron microscopy and Mrs Dr J. Vandenberg for the revision of the manuscript.

\section{REFERENCES}

Aluotto, B. B., Wittler, R. G., Williams, C. O. \& Faber, J. E. (1970). Standardized bacteriologic techniques for the characterization of Mycoplasma species. Int J Syst Bacteriol 20, 35-58.

Barber, T. L. \& Fabricant, J. (1971). Identification of Mycoplasmatales. Characterization procedures. Appl Microbiol 21, 600-605.

Barile, M. F. \& Kern, J. (1971). Isolation of Mycoplasma arginini from commercial bovine sera and its implication in contaminated cell cultures. Proc Soc Exp Biol Med 138, 432-437.

Boatman, E. S. (1979). Morphology and ultrastructure of Mycoplasmatales. In The Mycoplasmas, vol. 1, pp. 63-102. Edited by M. F. Barile \& S. Razin. New York: Academic Press.

Carle, P., Saillard, C. \& Bové, J. M. (1983a). DNA extraction and purification. In Methods in Mycoplasmology, vol. 1, pp. 295-299. Edited by S. Razin \& J. G. Tully. New York: Academic Press.

Carle, P., Saillard, C. \& Bové, J. M. (1983b). Determination of $\mathrm{G}+\mathrm{C}$ content of DNA. In Methods in Mycoplasmology, vol. 1, pp. 301-308. Edited by S. Razin \& J. G. Tully. New York: Academic Press.

Carle, P., Laigret, F., Tully, J. G. \& Bové, J. M. (1995). Heterogeneity of genome sizes within the genus Spiroplasma. Int J Syst Bacteriol 45, 178-181.

Clyde, W. A., Jr (1964). Mycoplasma species identification based upon growth inhibition by specific antisera. J Immunol $\mathbf{9 2}$, 958-965.

Edward, D. G. (1971). Determination of sterol requirement for Mycoplasmatales. J Gen Microbiol 69, 205-210.

Edward, D. G. \& Fitzgerald, W. A. (1951). Cholesterol in the growth of organisms of the pleuropneumonia group. $J$ Gen Microbiol 5, 576-586.

Fabricant, J. \& Freundt, E. A. (1967). Importance of extension and standardization of laboratory tests for the identification and classification of mycoplasma. Ann NY Acad Sci 143, 50-58.

Fallon, R. J. \& Whittlestone, P. (1969). Isolation, cultivation and maintenance of mycoplasmas. In Methods in Microbiology, vol. 3B, pp. 211-267. Edited by J. R. Norris \& D. W. Robbins. New York: Academic Press.

Freundt, E. A., Andrews, B. B., Ernø, H., Kunze, M. \& Black, F. T. (1973). The sensitivity of Mycoplasmatales to sodiumpolyanethol-sulfonate and digitonin. Zbl Bakteriol Parasitenkd Infektionskr Hyg Abt I Orig Reihe A 225, 104-112. 
Gardella, R. S., Del Giudice, R. A. \& Tully, J. G. (1983). Immunofluorescence. In Methods in Mycoplasmology, vol. 1, pp. 431-439. Edited by S. Razin \& J. G. Tully. Academic Press: New York.

Hill, A. C. (1971). Mycoplasma caviae, a new species. J Gen Microbiol 65, 109-113.

Hill, A. C. (1977). The metabolic inhibition test for mycoplasmas based on phosphatase production. J Hyg 79, 391-393.

Hill, A. C. (1978). Demonstration of mycoplasma in tissue by the immunoperoxidase technique $J$ Infect Dis 137, 152-154.

International Committee on Systematic Bacteriology Subcommittee on the Taxonomy of Mollicutes (1995). Revised minimal standards for descriptions of new species of the class Mollicutes (division Tenericutes). Int J Syst Bacteriol 45, 605-612.

Karnovsky, M. J. (1971). Use of ferrocyanide-reduced osmium tetraoxide in electron microscopy. Cell Biol 51, 146.

Klieneberger-Nobel, E. (1962). Morphology of pleuropneumonia-like organisms. In Pleuropneumonia-like organisms (PPLO) Mycoplasmataceae, pp. 23-56. Edited by E. Klieneberger-Nobel. Academic Press: New York.

Leach, R. H. (1976). The inhibitory effect of arginine on growth of some mycoplasmas. J Appl Bacteriol 41, 259-264.

Manchee, R. J. \& Taylor-Robinson, D. (1968). Haemadsorption and haemagglutination by mycoplasmas. J Gen Microbiol 50, 465-478.

Morton, H. E. \& Roberts, R. J. (1967). Production of antimycoplasma (PPLO) antibodies in rabbits. Proc Soc Exp Biol Med 125, 538-543.

Pearson, W. R. (1990). Rapid and sensitive sequence comparison with FASTP and FASTA. Methods Enzymol 183, 63-98.

Polak-Vogelzang, A. A., Hagenaars, R. \& Nagel, J. (1978). Evaluation of an indirect immmunoperoxidase test for identification of Acholeplasma and Mycoplasma. J Gen Microbiol 106, 241-249.

Polak-Vogelzang, A. A., Reijgers, R. \& Hekkens, F. E. N. (1980). Isolation of Mycoplasma hyorhinis and Mycoplasma fermentans from cell cultures. J Biol Stand 8, 243-254.

Purcell, R. H., Taylor-Robinson, D., Wong, D. C. \& Chanock, R. M. (1966a). A color test for the measurement of antibody to the non-acid-forming human Mycoplasma species. Am J Epidemiol 84, 51-66.

Purcell, R. H., Taylor-Robinson, D., Wong, D. C. \& Chanock, R. M. (1966b). Color test for the measurement of antibody to T-strain mycoplasmas. J Bacteriol 92, 6-12.

Razin, S. \& Tully, J. G. (1970). Cholesterol requirement of mycoplasma. J Bacteriol 102, 306-310.
Rose, D. L., Tully, J. G., Bové, J. M. \& Whitcomb, R. F. (1993). A test for measuring growth responses of Mollicutes to serum and polyoxyethylene sorbitan. Int J Syst Bacteriol 43, 527-532.

Shepard, M. C. \& Howard, D. R. (1970). Identification of ' $T$ ' mycoplasmas in primary agar cultures by means of a direct test for urease. Ann NY Acad Sci 174, 809-819.

Taylor-Robinson, D., Purcell, R. H., Wong, D. C. \& Chanock, R. M. (1966). A colour test for the measurement of antibody to certain mycoplasma species based upon the inhibition of acid production J Hyg 64, 91-104.

Taylor-Robinson, D., Williams, M. H. \& Haig, D. A. (1968). The isolation and comparative biological and physical characteristics of T-mycoplasmas of cattle. J Gen Microbiol 54, 33-46.

Timms, L. (1967). Isolation and identification of avian mycoplasmas. J Med Lab Technol 24, 79-89.

Tully, J. G. (1965). Biochemical, morphological and serological characterization of mycoplasma of murine origin. J Infect Dis 115, 171-185.

Tully, J. G. (1996). Diagnosis of mycoplasma infections of cell cultures - introductory remarks. In Molecular and Diagnostic Techniques in Mycoplasmology, vol. 2, pp. 407-410. Edited by J. G. Tully \& S. Razin. San Diego: Academic Press.

Tully, J. G. \& Razin, S. (1969). Characteristics of a new sterol nonrequiring mycoplasma. J Bacteriol 98, 970-978.

Tully, J. G., Whitcomb, R. F., Clark, H. F. \& Williamson, D. L. (1977). Pathogenic mycoplasmas: cultivation and vertebrate pathogenicity of a new spiroplasma. Science 195, 892-894.

Tully, J. G., Rose, D. L., Carle, P., Bové, J. M., Hackett, K. J. \& Whitcomb, R. F. (1988). Acholeplasma entomophilum sp. nov. from gut contents of a wide range of host insects. Int $J$ Syst Bacteriol 38, 164-167.

Tully, J. G., Bové, J. M., Laigret, F. \& Whitcomb, R. F. (1993). Revised taxonomy of the class Mollicutes: proposed elevation of a monophyletic cluster of arthropod-associated mollicutes to ordinal rank (Entomoplasmatales ord. nov.), with provision for familial rank to separate species with nonhelical morphology (Entomoplasmataceae fam. nov.) from helical species (Spiroplasmataceae), and emended descriptions of the order $\mathrm{Myco-}$ plasmatales, family Mycoplasmataceae. Int J Syst Bacteriol 43, 378-385.

Williams, C. O. \& Wittler, R. G. (1971). Hydrolysis of aesculin and phosphatase production by members of the order Мycoplasmatales which do not require sterol. Int J Syst Bacteriol 21, 73-77.

Williamson, D. L., Tully, J. G., Rosen, L., Rose, D. L., Whitcomb, R. F., Abalain-Colloc, M. L., Carle, P., Bové, J. M. \& Smith, J. (1996). Spiroplasma diminutum sp. nov., from Culex annulus mosquitoes collected in Taiwan. Int J Syst Bacteriol 46, 229-233. 